\title{
Tropical cattle: a reappraisal
}

\author{
J. P. Maule \\ Formerly Director, Commonwealth Bureau of Animal Breeding and Genetics, Edinburgh
}

\section{Introduction}

The failure and high cost of keeping crossbred cattle in many, but not all, parts of the tropics must focus attention on the possibilities of making greater use of the best indigenous breeds. The value of some breeds is already recognized, but there are others, not so well known, that might, by careful management, be improved and more widely used. The performance of some of the best indigenous breeds is illustrated below.

\section{Beef breeds}

There are several outstanding breeds in southern Africa. Two of these are the Mashona and Tuli whose homeland is Zimbabwe; others are the Nkone, Angoni and Barotse and, in East Africa, the Boran.

Mashona bulls have been performance recorded regularly at Makaholi for many years. Tuli bulls have been used in both Botswana and Zimbabwe in a large-scale project begun in 1972 at Matopos Research Station in Zimbabwe. Fertility, survival and maternal traits of the indigenous breeds compared favourably with those of the exotic breeds Charolais and Sussex as did growth (Figure 1) and carcass

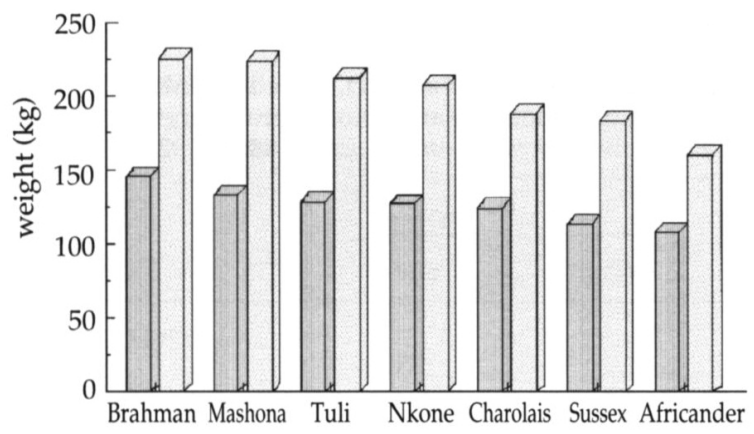

Figure 1 The Matoposexperiment: performance of indigenous and imported breeds 1979-1986. Theight of weaned calf per cow per year $(\mathrm{kg})$; $\square$ weight of 18 -month-old calf per cow per year (kg). quality. On the basis of size the smaller Mashona gave the best results.

\section{Dual-purpose breeds}

Outstanding among these is the Sahiwal an IndoPakistani breed widely used in the development of tropically adapted breeds. The Kenya Sahiwal was bred from imported stock (1939-50) and is now regarded as a valuable breed for both milk and beef in East Africa. The principal herd is at Naivasha where it was established in 1962. The improvement in milk yield obtained over an 8-year period is shown in Figure 2. Calves are separated at birth and cows give their milk without difficulty. This is an example of what can be achieved by good management.

\section{The Criollo project at Santa Cruz, Bolivia}

This is part of a larger project to cross the progeny of imported Holstein and Brown Swiss cows with Criollo bulls in the lowlands of Bolivia. Because of the decline of the Criollo breed it was necessary to establish a Criollo herd. One hundred cows were purchased from some $\mathbf{5 0}$ farms and semen of six dairy Criollo bulls was imported from Costa Rica. The aim is to increase the herd to 300 breeding cows when selection and progeny testing will be possible.

As the cows do not readily let down their milk, calves have to be suckled and are allowed only one teat. Calf mortality is low (6.7\%). Heifers are mated at $300 \mathrm{~kg}$ live weight and calve at 34 months. Cows are only given concentrates for yields above 4 $\mathrm{kg} /$ day.

Of the cows born on the station that have completed three lactations, $49 \%$ have given between 2000 and $3000 \mathrm{~kg}$ per lactation (including the amount taken by the calf) and $3 \%$ have exceeded $3200 \mathrm{~kg}$ (700 gallons).

The results of this project have shown that Criollo cattle have a commercial rôle as purebreds. 


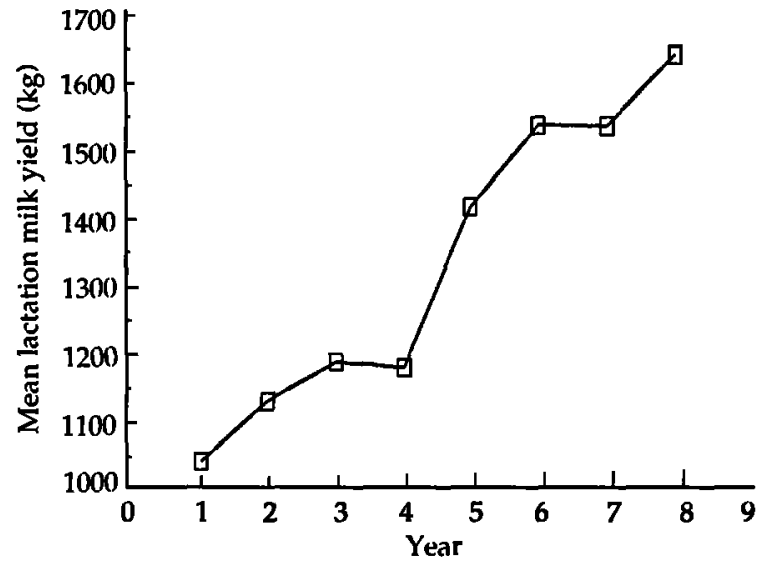

Figure 2 Improvement in milk yicld over an 8-year period in Sahiwal cattle of Naivasha herd.

\section{Some potentially useful breeds}

There are several other breeds which may have been undervalued and which would respond to improved management and selection. Three such breeds are as follows.

\section{(1) Jiddu (also called Tuni and Surco)}

A native of Somalia but also bred in Kenya and Tanzania. Lactation yields of over $1800 \mathrm{~kg}$ in 300 days have been recorded in Kenya and Tanzania.

(2) Wadera (also called Shuzua or Shuwa Arab) Found in North-east Nigeria, South Chad and North Cameroon. Although herds were established as long ago as the 1920s information is scarce and no attempt has been made to improve the breed. In one herd, lactation yields of up to $1770 \mathrm{~kg}$ were obtained and the breed is considered to give higher yields of milk than any other Nigerian breed.

\section{(3) Gir}

This is an Indian breed from Gujerat State but Gir cattle were exported to Brazil in the 19th century and their milking qualities were improved. They are now said to be declining in numbers. Milk yields reported in the 1970s and early 1980s were higher than those obtained in India and among the highest of any zebu breed, one report giving a yield of $2788 \mathrm{~kg}$ for nearly 2000 lactations.

\section{Conclusions}

1. There is sufficient evidence to show that the performance of some indigenous breeds compares favourably with that of 'European' beef breeds under range conditions.

2. Indigenous cattle have certain advantages - they live longer, calf mortality is lower, they cost less to keep and provide better draught animals than crossbreeds.

3. The success achieved in raising milk yields in a few breeds shows that, with good management, other breeds could be improved. Yields of 1800 $\mathrm{kg} /$ year obtained at low cost may be more profitable than larger yields from imported or crossbred herds given expensive concentrates.

4. There are many areas where indigenous breeds could, and should be improved, but, to be successful, a sound breeding policy and proper system of evaluation is essential. 